\section{Variation in micronutrient and macronutrient concentrations in grain of four wheat geno- types grown in Albaha region, Saudi Arabia}

\author{
Fatima Omari Alzahrani \\ Department of Biology, Faculty of \\ Science, Albaha University, Albaha, \\ Saudi Arabia
}

\begin{abstract}
Major dependence on wheat-based foods with low bioavailability of nutrients led to high malnutrition rates, especially in developing counties. Four wheat genotypes (Albelad (BE), Aldwasair (AD), Australia $(\mathrm{AU})$ and Najran (NJ)) grown in Albaha region were analyzed for the first time for the variation in micronutrient $(\mathrm{Se}, \mathrm{Mo}, \mathrm{Cu}$, $\mathrm{Zn}, \mathrm{Mn}, \mathrm{Fe}, \mathrm{B}$ and $\mathrm{Na}$ ) and macronutrient concentrations $(\mathrm{P}, \mathrm{Ca}, \mathrm{Mg}$ and $\mathrm{K})$ in the whole wheat grain using Inductively coupled plasma mass spectrometry (ICP-MS) in order to select genotype of high nutritional value of the wheat for human consumption for further breeding by farmers. Substantial micronutrient variation existed among the four genotypes according to their mean $\mathrm{Se}, \mathrm{Mo}, \mathrm{Zn}$, and $\mathrm{Na}$ concentrations, while macronutrient variation existed in their $\mathrm{P}$ and $\mathrm{Ca}$ concentrations. The NJ genotype appeared to contain higher concentrations of $\mathrm{Se}, \mathrm{Na}$, and $\mathrm{Ca}$ than the other genotypes while AU contained higher concentrations of $\mathrm{Zn}$ and $\mathrm{P}$ than $\mathrm{AD}, \mathrm{BE}$, or NJ. The results of this study can provide information about micro- and macro-nutrient enriched wheat genotypes for agricultural strategies aimed at improving the nutritional value of wheat plants.
\end{abstract}

\section{Introduction}

Minerals are a huge group of chemicals that are considered very important for human health. Minerals are usually categorized into two groups, micronutrients (minerals required in small quantities) and macronutrients (minerals required in large quantities). Wheat is considered a rich source of minerals and variability in wheat mineral composition has been reported in several papers. ${ }^{1,2}$ A study reported that there were substantial differences in mineral compositions between primitive wheat, old genotypes, and more modern wheat materials. ${ }^{3}$ Macro- and micronutrient malnutrition is a serious health issue worldwide that is usually called "hidden hunger." It specifically impacts people living in developing countries but may occur even in developed countries. ${ }^{4,5}$ The human body requires about 49 nutrients to sustain good health. ${ }^{5}$ A deficiency in one of these nutrients usually leads to negative effect on the human body and negative health consequences that may require special attention, especially in children. ${ }^{5}$ Agricultural products are considered the major primary source of nutrients, contributing greatly to supporting healthy lifestyles. ${ }^{6}$ However, in many developing countries the agriculture sector fails to provide the required amount of nutrients. ${ }^{7}$ It was estimated that three billion people suffer from malnutrition, and the evidence suggests that the number is increasing. ${ }^{8}$ Wheat is a type of grass that belongs to the Gramineae family. It is considered one of the most important crops, as it is the main food for two-thirds of the world's population and is cultivated in large parts of the world, including Saudi Arabia. It is a winter crop of strategic importance and plays a major role in international politics and its lack is a threat to food security of any country. Wheat and other cereal crops represent a major dietary component for many people, especially those living in developing countries, and it is the third most universally consumed cereal crop by weight, after rice and maize. ${ }^{9}$ However, there is a scarcity of nutrients in wheat genotypes, believed to be caused by two factors. ${ }^{10}$ First, the grain preparation process before consumption usually includes milling and/or polishing to enable their further use for product manufacture or cooking, which result in alteration of their nutritional quality. ${ }^{11}$ Second, farmers prefer wheat genotypes with enhanced yields, regardless of grain quality or nutrient content. ${ }^{2}$ Biofortification has emerged as a new tool to enhance micronutrient concentrations via conventional and molecular plant breeding, genetic modification, and agronomic interventions involving suitable fertilizer applications. ${ }^{7}$ Developing new genotypes biofortified with nutrients, by breeding or genetic engineering, requires knowledge of the variation in nutrient traits among the available germplasm. As has been mention earlier there are several encouraging examples of screening studies on wheat genotypes that demonstrate
Correspondence: Fatima Omari Alzahrani, Department of Biology, Faculty of Science, Albaha University, Albaha city, 65527, Albaha province, Saudi Arabia.

Tel.: +966.177257700 (13100)

E-mail: drfatimaomari@gmail.com

Key words: mineral, elements, nutrition, malnutrition, ICP-MS

Acknowledgements: The author would thank the Deanship of Scientific Research, Albaha University, Saudi Arabia for the financial support.

Conflict of interest: The author declares no potential conflict of interest.

Funding: This research was funded by the Deanship of Scientific Research, Albaha University, Saudi Arabia (Grant No. 12-1439).

Received for publication: 22 January 2020. Accepted for publication: 1 October 2020.

This work is licensed under a Creative Commons Attribution-NonCommercial 4.0 International License (CC BY-NC 4.0).

${ }^{(C)}$ Copyright: the Author(s), 2021

Licensee PAGEPress srl, Italy

International Journal of Plant Biology 2021; 12:8788 doi:10.4081/pb.2021.8788

significant variation in micro- and macronutrient concentrations, however, to the best of our knowledge there is no such study has been conducted on wheat genotypes grown in Albaha region. Although Albaha region's contribution to the global and local production of wheat is low, there is many people who depend on wheat that grown in the local farms. Therefore, the aim of this study is to quantify baseline variations in micro- and macronutrient concentrations among four wheat grain genotypes grown in the Albaha region [namely, Albelad (BE), Aldwasair (AD), Australia $(\mathrm{AU})$, and Najran (NJ)]. This will improve the nutritional health of target populations by representing a wide range of diversity in the available gene pool and ensuring the human health impacts before advancing particular genotypes in breeding programs to the local farmers in the region. Hence, this study will analyze the wheat genotypes for a several of important minerals, including micro- and macronutrients whereas most previous studies tend to focus on only one. 
Canada). Sample processing was undertaken using Qtegra ${ }^{\mathrm{TM}}$ software (Thermo Fisher Scientific).

\section{Wheat genotypes}

The wheat genotypes used in the study were grown during 2017 in the Albaha region of Saudi Arabia. We used four wheat genotypes: Albelad (BE), Aldwasair (AD), Australia (AU), and Najran (NJ). Table 1 demonstrates the physical parameters of the wheat genotypes used in this study. The micronutrient included in this study are Selenium (Se), Molybdenum (Mo), Copper $(\mathrm{Cu})$, Zink $(\mathrm{Zn})$, Manganese $(\mathrm{Mn})$, Iron (Fe), and Boron (B) Sodium (Na) While the macronutrients included are Phosphorus (P), Calcium (Ca), Magnesium ( $\mathrm{Mg})$, and Potassium (K).

\section{Multi-element analysis}

Prior to the determination of the different element concentrations, about $50 \mathrm{~g}$ of each genotype were washed separately using distilled water and kept for drying in incubator at $45^{\circ} \mathrm{C}$ for 2 days. Dried samples were digested with $6 \mathrm{~mL} \mathrm{HNO}_{3}$ using a microwave oven (Anton PaarGmbh, Graz, Austria). Grain samples of approximately $0.2 \mathrm{~g}$ were placed into digestion tubes, their weight was recorded, and then $6 \mathrm{~mL}$ concentrated $\mathrm{HNO}_{3}$ was pipetted into each tube. The digestion tubes were then placed into a numbered position in the microwave rotor. Two tubes of certified reference material (CRM-wheat flour, 1567b), two laboratory reference material (LRM- wheat flour) and two blanks $\left(6 \mathrm{~mL} \mathrm{HNO}_{3}\right)$ were included. A high-temperature grain program was selected for the microwaving, and the digestion lasted for about 60 mins. The samples were digested using the following heating program: heat to $175^{\circ} \mathrm{C}$ within a ramp time of 20 mins at a power of $1500 \mathrm{~W}$, hold for $20 \mathrm{~min}$ at $175^{\circ} \mathrm{C}$, and then cool at $55^{\circ} \mathrm{C}$ for $10 \mathrm{~min}$.

Once digestion was completed, the digestion tubes were opened, a final volume of $24 \mathrm{~mL}$ was produced by adding $18 \mathrm{~mL}$ of Milli-Q water. The samples were transferred to labeled universal tubes for storage until use. Digested samples of $1 \mathrm{~mL}$ were placed into ICP tubes and $9 \mathrm{~mL}$ milli-Q water was added to each tube. The samples were then mixed and sent for multi-element analysis.

Elements analysis was carried out using an inductively coupled plasma mass spectrometer (iCAP Q ICP-MS, Thermo Fisher Scientific, Bremen, Germany). Samples were introduced from an auto sampler incorporating an ASXpress ${ }^{\mathrm{TM}}$ rapid uptake module (Cetac ASX-520, Teledyne Technologies Inc., Omaha, NE, USA) through a PEEK nebuliser (Burgener Mira Mist, Burgener Research Inc., Mississauga,

\section{Statistical analysis}

The experiments were performed in triplicate, and the average values and standard deviations were calculated using SPSS 21.0 for Windows (SPSS Inc., Chicago, IL, USA). Statistical comparisons were estimated by one-way ANOVA and Duncan's multiple-range tests at $\mathrm{p}<0.05$.

\section{Results}

For the differences in micronutrient mineral concentrations between the four genotypes (Table 2), there was a significant difference in Se concentrations between the different genotypes $(\mathrm{P}<0.05)$ with NJ having the highest concentration and $\mathrm{AD}$ the lowest (Table 2). Mo concentration differed significantly between the genotypes ranging from to $0.47 \pm 0.01$ to $0.68 \pm 0.04 \mathrm{mg} / \mathrm{kg}$ DW (Table 2).

$\mathrm{Cu}$ had similar concentrations in all genotypes ranging from $3.87 \pm 0.16 \mathrm{mg} / \mathrm{kg}$ DW to $4.78 \pm 0.40 \mathrm{mg} / \mathrm{kg}$ DW and the $\mathrm{p}$ value was higher than 0.05 . Zn concentration was the highest in $\mathrm{AU}(30.69 \pm 1.25$ $\mathrm{mg} / \mathrm{kg} \mathrm{DW}$ ) and the lowest value was observed in NJ $(17.15 \pm 0.67 \mathrm{mg} / \mathrm{kg}$ DW $)$ $(\mathrm{p}>0.05)$. Mn concentration was similar in $\mathrm{AD}$ and $\mathrm{AU}(35.74 \pm 1.92 \mathrm{mg} / \mathrm{kg}$ DW and $35.15 \pm 4.25 \mathrm{mg} / \mathrm{kg} \mathrm{DW}$ ), whereas it was $28.18 \pm 0.85 \mathrm{mg} / \mathrm{kg}$ DW and $38.97 \pm 022$ $\mathrm{mg} / \mathrm{kg}$ DW in BE and NJ, respectively $(p>0.05)$. Fe concentration was similar in all genotypes, ranging from $26.86 \pm 1.25$ $\mathrm{mg} / \mathrm{kg}$ DW to $28.86 \pm 0.53 \mathrm{mg} / \mathrm{kg} \mathrm{DW}$, and no significant differences in Fe concentration were observed in the four wheat genotypes $(\mathrm{p}>0.05)$. The B concentration reached $0.98 \pm 0.51 \mathrm{mg} / \mathrm{kg} \mathrm{DW}$ in $\mathrm{AU}$, and $0.77 \pm 0.47 \mathrm{mg} / \mathrm{kg}$ DW and $0.0 .78 \pm 0.50$ $\mathrm{mg} / \mathrm{kg} \mathrm{DW}$ in $\mathrm{BE}$ and $\mathrm{AD}$, respectively. The lowest concentration was observed in NJ, $0.65 \pm 0.33 \mathrm{mg} / \mathrm{kg} \mathrm{DW}$, but the differences were not statically significant $(\mathrm{p}>0.05)$. The $\mathrm{Na}$ concentration was comparable between $\mathrm{BE}$ and $\mathrm{AU}$ (Table 2). However, the AD genotype was shown to contain less $\mathrm{Na}$ than the NJ genotype.

The concentrations of a number of macronutrients are presented in Table 3. The table shows that there were some variations in macronutrient concentration in all four genotypes. The $\mathrm{P}$ concentration was comparable between $\mathrm{BE}$ and $\mathrm{AU}$ (Table 3). The $\mathrm{Ca}$ concentrations were above 500 $\mathrm{mg} / \mathrm{kg} \mathrm{DW}$ in BE, AU, and NJ but the concentration was about $404.64 \pm 13.88 \mathrm{mg} / \mathrm{kg}$
$\mathrm{DW}$ in the AD genotype. There was a variation in $\mathrm{Mg}$ concentrations in all four genotypes ranging from $1218.47 \pm 53.15 \mathrm{mg} / \mathrm{kg}$ DW to $1574.04 \pm 132.18 \mathrm{mg} / \mathrm{kg}$ DW with no significant differences between the examined values $(p>0.05)$. The concentration of $\mathrm{K}$ was highest in the $\mathrm{BE}$ genotype $(5245.39 \pm 226.09 \mathrm{mg} / \mathrm{kg} \mathrm{DW})$, and lowest in $\mathrm{AD}(4649.37 \pm 166.5 \mathrm{mg} / \mathrm{kg} \mathrm{DW})$; however, this variation was also not statically significant $(\mathrm{p}>0.05)$.

\section{Discussion}

Although the primary objective of plant breeding programs has been historically oriented toward high agronomic yield, the nutritional value of staple food crops, which tends to be overlooked, remains an important quest. ${ }^{12}$ Directed efforts of biofortification of wheat genotypes requires knowledge of wheat germplasm for grain mineral concentration. ${ }^{13}$ Thus, determining micro- and macronutrient -enriched wheat genotypes is important in order to address malnutrition in developing countries such as in Saudi Arabia.

Although Se was previously considered to possess toxic properties, it was later shown to play an essential role in physiological processes and to display antioxidant, anti-cancer, and anti-viral characteristics. $^{14,15}$ The agronomic biofortification of crops to enhance their Se content, with the aim of correcting for Se deficiencies in the human body, revealed that it has another substantial role in the adjustment of plant water status under drought conditions. ${ }^{16}$ Regarding the application of Se to crops, it was reported that foliar application of $\mathrm{Se}$ enhanced the yield and nutrient quality of wheat plants more effectively than other methods that included crop fertigation and Se seed biopriming. ${ }^{17}$ A study reported that there was no significant variation in grain Se concentration among modern wheat genotypes grown in Mexico and Australia; however, variation was shown to exist among Aegilops tauschii and rye genotypes. ${ }^{18}$

The agronomic biofortification of wheat with $\mathrm{N}$ and/or $\mathrm{S}$ was demonstrated to have a potential for altering the $\mathrm{Se}$ content in wheat grain. ${ }^{19}$ In addition, biofortification with $\mathrm{Zn}$ in combination with $\mathrm{Se}$ was observed to enhance the accumulation of Se in the grain of Brazilian wheat lines. ${ }^{20}$ Interestingly, the mean Se concentration was found to remain constant over a 17year period in a study on bread-making wheat lines ( $T$. aestivum) from different regions around the UK. and the Se concentrations were $0.025,0.033$, and $0.025 \mathrm{mg} / \mathrm{kg}$ 
in 1982, 1992, and 1998, respectively, which appear to be lower values than those presented in our study. ${ }^{21}$ In fact, in the same study it was highlighted that the application of $\mathrm{S}$ to wheat lines caused a dramatic decline in grain Se concentration. ${ }^{21}$

Mo is considered to be an important micronutrient for sustaining good health and Mo deficiency is associated with increased risk of esophageal cancer. ${ }^{22} \mathrm{~A}$ negative relationship was observed between the Mo concentration in wheat grain and the application of $\mathrm{S}$ to the soil in a long-term Swedish soil fertility experiment conducted between 1967 and 2003. ${ }^{23}$ The Mo concentration was shown to reach $1.2 \mathrm{mg} / \mathrm{kg} \mathrm{DW}$ in the grain of Triticum monococcum, which is higher than the observed mean value in the present study in all four genotypes. ${ }^{24}$

In a study conducted to evaluate the genetic variation and environmental stability of grain mineral nutrient concentrations in Triticum dicoccoides, the variations in $\mathrm{Cu}$ concentration were attributed to the genotype. ${ }^{1}$ The mean $\mathrm{Cu}$ concentrations were reported to be 4.0, 4.1, 5.0, and $3.9 \mathrm{mg} / \mathrm{kg}$ in the T. monococcum, Triticum dicoccum, Triticum spelta, and T. aestivum genotypes, which are similar to the results obtained in the current study. ${ }^{24}$

It was reported that variation in $\mathrm{Zn}$ concentration among modern wheat genotypes is limited and the existing variation is mainly attributed to environmental and manage- ment factors, not genotypic variation. ${ }^{25}$ In contrast, variation in $\mathrm{Zn}$ concentration among wild wheat relatives was observed to be high, hence them serving as a genetic resource for increasing $\mathrm{Zn}$ concentrations in modern cultivars. ${ }^{25}$ This high genetic diversity in $\mathrm{Zn}$ content in the wild wheat relatives was likewise detected under two contrasting irrigation regimes: a well-watered control and a water-limited treatment. ${ }^{26}$ The mean $\mathrm{Zn}$ concentration in wheat grain has been reported to reach $89 \mathrm{mg} / \mathrm{kg}$, while Peleg et al. reported a $\mathrm{Zn}$ concentration of 125 $\mathrm{mg} / \mathrm{kg} \mathrm{DW}$, which is much larger than the mean values in the four genotypes in the present study. ${ }^{25,26}$ In addition, variation in $\mathrm{Zn}$ concentration was reported to exist

Table 1. Physical parameters of wheat genotypes.

\begin{tabular}{|c|c|c|c|c|c|c|c|}
\hline \multirow[t]{2}{*}{ Genotype } & \multirow[t]{2}{*}{ N. wheat grains per $50 \mathrm{~g}$} & \multirow[t]{2}{*}{ Means $\pm \mathrm{SE}$} & \multicolumn{2}{|c|}{ Grain length, mm } & \multicolumn{2}{|c|}{ Grain width, mm } & \multirow[t]{2}{*}{ Grain sike } \\
\hline & & & m & $\mathbf{r}$ & m & $\mathbf{r}$ & \\
\hline $\mathrm{BE}$ & $\begin{array}{l}1653 \\
1712 \\
1682\end{array}$ & $1682.33 \pm 17.03^{\mathrm{a}}$ & 5.7 & $\begin{array}{l}6 \\
5 \\
6\end{array}$ & 4 & $\begin{array}{l}4 \\
4 \\
4\end{array}$ & Short \\
\hline $\mathrm{AD}$ & $\begin{array}{l}1129 \\
1150 \\
1133\end{array}$ & $1137.33 \pm 6.44^{\mathrm{d}}$ & 7 & $\begin{array}{l}7 \\
7 \\
7\end{array}$ & 4 & $\begin{array}{l}4 \\
4 \\
4 \\
\end{array}$ & Long \\
\hline $\mathrm{AU}$ & $\begin{array}{l}1329 \\
1358 \\
1328\end{array}$ & $1338.33 \pm 9.84^{\mathrm{c}}$ & 7.5 & $\begin{array}{l}7.5 \\
7.5 \\
7.5\end{array}$ & 3 & $\begin{array}{l}3 \\
3 \\
3\end{array}$ & Long \\
\hline NJ & $\begin{array}{l}1469 \\
1488 \\
1434\end{array}$ & $1463.67 \pm 15.81^{b}$ & 6.2 & $\begin{array}{c}6 \\
6.5 \\
6\end{array}$ & 3.8 & $\begin{array}{c}4 \\
3.5 \\
4\end{array}$ & Medium \\
\hline
\end{tabular}

Column means followed by different letters are significantly different at $\mathrm{p}<0.05$. Labels: Albelad (BE), Aldwasair (AD), Australia (AU) and Najran (NJ).

Table 2. Grain concentrations ( $\mathrm{mg} / \mathrm{kg} \mathrm{DW}$ ) of mineral micronutrient elements of the four wheat genotypes.

\begin{tabular}{|c|c|c|c|c|c|}
\hline & E means $\pm S$. & AD means \pm S.E & AU means $\pm S . E$ & NJ means \pm S.E & P values \\
\hline $\mathrm{Se}$ & $0.06 \pm 0.00$ & $0.03 \pm 0.00$ & $0.07 \pm 0.01$ & $0.09 \pm 0.00$ & $0.01^{*}$ \\
\hline Mo & $0.47 \pm 0.01$ & $0.68 \pm 0.04$ & $0.53 \pm 0.04$ & $0.51 \pm 0.02$ & $0.01^{*}$ \\
\hline $\mathrm{Cu}$ & $3.87 \pm 0.16$ & $4.18 \pm 0.23$ & $4.78 \pm 0.40$ & $4.02 \pm 0.08$ & 0.13 \\
\hline Zn & $28.54 \pm 0.53$ & $27.44 \pm 0.89$ & $30.69 \pm 1.25$ & $17.15 \pm 0.67$ & $0.00^{* *}$ \\
\hline $\mathrm{Mn}$ & $28.18 \pm 0.85$ & $35.74 \pm 1.92$ & $35.15 \pm 4.25$ & $38.97 \pm 022$ & 0.06 \\
\hline $\mathrm{Fe}$ & $27.42 \pm 1.26$ & $27.82 \pm 0.95$ & $26.86 \pm 1.25$ & $28.86 \pm 0.53$ & 0.60 \\
\hline B & $0.77 \pm 0.47$ & $0.78 \pm .50$ & $0.65 \pm 0.33$ & $0.98 \pm 0.51$ & 0.96 \\
\hline $\mathrm{Na}$ & $84.19 \pm 9.52$ & $116.77 \pm 21.23$ & $80.98 \pm 14.81$ & $161.78 \pm 6.48$ & $0.012 *$ \\
\hline
\end{tabular}

*The mean difference is significant at the 0.05 level.

Table 3. Grain concentrations (mg/kg DW) of mineral macronutrient elements of the four wheat genotypes.

\begin{tabular}{|c|c|c|c|c|c|}
\hline & BE means $\pm S . E$ & AD means \pm S.E & AU means $\pm S . E$ & $\mathrm{NJ}$ means $\pm \mathrm{S} . \mathrm{E}$ & P values \\
\hline $\mathrm{P}$ & $3791.44 \pm 139.2$ & $3432.99 \pm 85.9$ & $3854 \pm 250.8$ & $2695.26 \pm 136.7$ & $0.004^{*}$ \\
\hline $\mathrm{Ca}$ & $516.97 \pm 11.78$ & $404.64 \pm 13.88$ & $536.18 \pm 10.07$ & $538.10 \pm 16.28$ & $0.000 * *$ \\
\hline $\mathrm{Mg}$ & $1402.72 \pm 61.89$ & $1455.11 \pm 82.95$ & $1574.04 \pm 132.18$ & $1218.47 \pm 53.15$ & 0.107 \\
\hline $\mathrm{K}$ & $5245.39 \pm 226.09$ & $4649.37 \pm 166.5$ & $4835.88 \pm 245.25$ & $4746.15 \pm 290.47$ & 0.360 \\
\hline
\end{tabular}

*The mean difference is significant at the 0.05 level. 
among 150 lines of bread wheat representing diverse origins and in 25 lines of Durum, Spelt, Einkorn, and Emmer wheat. A negative correlation between grain $\mathrm{Zn}$ content and yield was also highlighted. ${ }^{10}$ Potassium chloride $(\mathrm{KCl})$ fertilizer was shown to positively affect the grain yield of wheat; however, this increase was associated with a decline of the $\mathrm{Zn}$ concentration in the grain. ${ }^{27}$ In the aforementioned study, soil type was shown to have an effect on $\mathrm{Zn}$ concentration, with $\mathrm{Zn}$ concentrations noticeably lower in clay loam than in fine sandy loam soil.

The mean $\mathrm{Mn}$ concentration was 28 $\mathrm{mg} / \mathrm{kg}$ DW in $T$. monococcum, which is similar to the concentration recorded for the $\mathrm{BE}$ genotype. ${ }^{24}$ However, the mean $\mathrm{Mn}$ concentration in 265 leading Chinese wheat cultivars and advanced wheat lines was 48.8 $\mathrm{mg} / \mathrm{kg}$ and huge variation was observed in the examined lines. ${ }^{28}$ The variation in Mn concentration within the 265 lines was mainly attributed to environmental effects. A substantial positive correlation was described among $\mathrm{Mn} \mathrm{Fe}, \mathrm{Zn}, \mathrm{Mg}$, and $\mathrm{P}$ concentrations. ${ }^{28}$

Positive correlations between Fe concentration and the yield, grain protein content, and $\mathrm{P}$ concentration were reported by. ${ }^{26}$ The Fe concentration in wild Emmer wheat under contrasting irrigation regimes was $85 \mathrm{mg} / \mathrm{kg}$. ${ }^{26}$ The mean Fe concentration in 265 leading Chinese wheat cultivars and advanced wheat lines was $39.2 \mathrm{mg} / \mathrm{kg}$, which is higher than the value reported in our study. ${ }^{28}$ Interestingly, a study pointed out that the decline of $\mathrm{Cu}, \mathrm{Zn}$, and $\mathrm{Fe}$ in wheat was associated with the introduction of high yield, semi-dwarf varieties. ${ }^{29}$

$\mathrm{B}$ is considered an essential micronutrient for the development of wheat. B deficiency in wheat has been observed in genotypes worldwide since the 1960 s. ${ }^{30}$ It leads to grain set failure caused by male sterility. ${ }^{30}$ The mean $\mathrm{B}$ concentration value in wheat is in the range of $0.6-0.8 \mathrm{mg} / \mathrm{kg}$, which is similar to the recoded values for $\mathrm{B}$ in the present study $(0.6-0.9 \mathrm{mg} / \mathrm{kg}){ }^{24}$

None of the mean $\mathrm{Na}$ concentration values for any of the four genotypes presented in our study agreed with the values reported by Suchowilska et $a .^{24}$ To conclude, the micronutrients $\mathrm{Se}, \mathrm{Mo}, \mathrm{Zn}$, and $\mathrm{Na}$ varied significantly among the four studied wheat genotypes.

All of the obtained $\mathrm{P}$ concentration values in this study were lower than the mean $P$ concentration value (4179) reported by Zhang et al. for 265 leading Chinese cultivars and advanced lines. ${ }^{28}$ The variation of $\mathrm{P}$ concentration among the 265 cultivars and lines was mainly attributed to environmental effects and to the genotypes via environment interactions. ${ }^{28}$ Positive correlations between the $\mathrm{Zn}$ and Fe concentrations and the grain $\mathrm{P}$ concentration in 150 lines of wheat were reported. ${ }^{10}$ Additionally, great variation in $\mathrm{P}$ concentration was observed in the whole grain of four Triticum spp. and it ranged from 4180 $\mathrm{mg} / \mathrm{kg}$ DW to $5200 \mathrm{mg} / \mathrm{kg} \mathrm{DW} .^{24}$

In a study conducted to evaluate $\mathrm{Ca}$ concentrations in a European wheat diversity panel of 353 varieties, the Ca concentration was found to range from 288.20 to $647.50 \mathrm{mg} / \mathrm{kg}$ DW. In addition, the Ca concentration ranged from $360 \mathrm{mg} / \mathrm{kg}$ DW to $420 \mathrm{mg} / \mathrm{kg} \mathrm{DW}$ in the whole grain of Emmer, Einkorn, Spelt, and two common wheat cultivars, while the mean Ca concentration value was $473 \mathrm{mg} / \mathrm{kg} \mathrm{DW}$ in the grain of 265 leading Chinese cultivars and advanced lines. ${ }^{24,28}$

The concentrations of both $\mathrm{Mg}$ and $\mathrm{K}$ were similar to the recorded mean values for $\mathrm{Mg}$ and $\mathrm{K}$ (1519 and $4847 \mathrm{mg} / \mathrm{kg} \mathrm{DW}$, respectively) in the micronutrient study on Chinese wheat cultivars. ${ }^{28}$ In addition, the concentrations of $\mathrm{Mg}$ presented in our study are within the range of $\mathrm{Mg}$ concentrations (from 1170 to $2020 \mathrm{mg} / \mathrm{kg} \mathrm{DW}$ ) reported by Suchowilska et $a l .{ }^{24}$ To conclude, the only significant macronutrient variations among the four studied wheat genotypes were for $\mathrm{P}$ and $\mathrm{Ca}$.

\section{Conclusions}

Macro- and micronutrient composition of wheat genotypes common in Albaha region has been studied for the first time. It is obvious from the results obtained, nutritional profile distinguished the four studied genotypes.

In terms of micronutrient variations, Se, $\mathrm{Mo}, \mathrm{Zn}$, and $\mathrm{Na}$ varied significantly among the four studied wheat genotypes. The Se concentration was highest in the NJ wheat genotype, the Mo concentration was highest in the AD genotype, and the $\mathrm{Zn}$ concentration was highest in the AU genotype. The $\mathrm{Na}$ concentration was higher in the NJ genotype than in any of the others. Regarding macronutrient variations, $\mathrm{P}$ and $\mathrm{Ca}$ varied significantly among all four of the studied wheat genotypes. The Ca concentration was higher in NJ genotype than in any of the others while the P concentration was higher in the AU genotype than in any of the others. Other than the NJ genotype, which had the highest accumulation of both Se and N, there were no genotypes that were rich in more than one micro- or macronutrient. The observed variability of $\mathrm{Se}, \mathrm{Mo}, \mathrm{Zn}, \mathrm{Na}, \mathrm{P}$, and $\mathrm{Ca}$ can be used to develop enriched wheat cultivars in wheat breeding programs and other genetic technologies to improve health of people consuming whole grain wheat products and food-processing industries.

The observed concentrations of a number of elements, such as Mo, Zn, Mn, Fe, and $\mathrm{P}$, were lower than those recorded in previous studies, suggesting a need to use wild wheat relatives or macro- and micronutrient-enriched wheat genotypes as genetic resources in breeding programs. Although soil type, climate, and cultivation practices may affect wheat grain traits such as micro- and macronutrient concentrations, genotype may explain the significant differences in the results of the current study. For micronutrient and macronutrient elements analysis, it is recommended that to include more genotypes from different regions in Saudi Arabia in order to import new genetic resources to the region. It is important to study the baseline effects of genotype $(\mathrm{G})$, site (E), and genotype by site interactions (GxE) on grain micronutrient and macronutrient elements concentration in order to obtain a comprehensive evaluation of factors effecting the quality and nutritional value of wheat grains.

\section{References}

1. Gomez-Becerra HF, Yazici A, Ozturk L, et al. Genetic variation and environmental stability of grain mineral nutrient concentrations in Triticum dicoccoides under five environments. Euphytica 2010;171:3952.

2.Guttieri MJ, Baenziger, PS, Frels K, et al. Variation for grain mineral concentration in a diversity panel of current and historical Great Plains hard winter wheat germplasm. Crop Science 2015;55:1035-52.

3. Hussain A, Larsson H, Kuktaite R, Johansson E. Mineral composition of organically grown wheat genotypes: contribution to daily minerals intake. Int J Env Res Pub Health 2010;7:3442-56.

4. Kennedy G, Nantel G, Shetty P. The scourge of "hidden hunger": global dimensions of micronutrient deficiencies. Food Nutr Agric 2003;32:8-16.

5. Welch RM, Graham RD. Breeding for micronutrients in staple food crops from a human nutrition perspective. J Exp Bot 2004;55:353-64.

6. Branca F, Ferrari M. Impact of micronutrient deficiencies on growth: the stunting syndrome. Ann Nutr Metab 2002;46: 8-17.

7. Sharma P, Aggarwal P, Kaur A. Biofortification: A new approach to 
eradicate hidden hunger. Food Rev Int 2017;33:1-21.

8. Umar M, Nawaz R, Sher A, et al. Current Status and Future Perspectives of Biofortification in Wheat. Asian J Crop Sci 2019;6:1-14.

9. Shiferaw B, Smale M, Braun HJ, et al. Crops that feed the world 10. Past successes and future challenges to the role played by wheat in global Food. Secur Food Secur 2013;5:291-317.

10. Zhao FJ, Su YH, Dunham SJ, et al., Variation in mineral micronutrient concentrations in grain of wheat lines of diverse origin. J Cereal Sci 2009;49:290-5.

11. Oghbaei M, Prakash J. Effect of primary processing of cereals and legumes on its nutritional quality: A comprehensive review. Cogent Food Agricult 2016;2:1136015.

12. Cakmak I, Pfeiffer WH, McClafferty B. Review: biofortification of durum wheat with zinc and iron. Cereal Chem J 2010;87:10-20.

13. Waters BM, Sankaran RP. Moving micronutrients from the soil to the seeds: genes and physiological processes from a biofortification perspective. Plant Sci 2011;180:562-74.

14. Combs GF. Selenium in global food systems. Br J Nutr 2001;85:517-47.

15. Bodnar M, Konieczka, Namiesnik J. The properties, functions, and use of selenium compounds in living organisms. J Environ Sci Health C 2012;30:225-52.
16. Gupta M, Gupta S. An overview of selenium uptake, metabolism, and toxicity in plants. Front Plant Sci 2017;7:2074.

17. Nawaz F, Ashraf MY, Ahmad R, et al. Supplemental selenium improves wheat grain yield and quality through alterations in biochemical processes under normal and water deficit conditions. Food Chem 2015;175:3507.

18. Lyons G, Ortiz-Monasterio I, Stangoulis J, Graham R. Selenium concentration in wheat grain: is there sufficient genotypic variation to use in breeding? Plant Soil 2005;269:369-80.

19. Duncan EG, Maher WA, Jagtap R, et al. Selenium speciation in wheat grain varies in the presence of nitrogen and sulphur fertilisers. Environ Geochem Health 2017;39:955-66.

20. Souza GA, Hart JJ, Carvalho JG, et al. Genotypic variation of zinc and selenium concentration in grains of Brazilian wheat lines. Plant Sci 2014;224:27-35.

21. Adams ML, Lombi E, Zhao FJ, McGrath SP. Evidence of low selenium concentrations in UK bread $\square$ making wheat grain. J Sci 2002;82:1160-5.

22. Nouri M, Chalian H, Bahman A, et al. Nail molybdenum and zinc contents in populations with low and moderate incidence of esophageal cancer. Arch Iran Med 2008;11:392-6.

23. Kirchmann H, Mattsson L, Eriksson J. Trace element concentration in wheat grain: results from the Swedish longterm soil fertility experiments and national monitoring program. Environ Geochem Health 2009;31:561-71.

24. Suchowilska E, Wiwart M, Kandler W, Krska RA. Comparison of macro-and microelement concentrations in the whole grain of four Triticum species. Plant Soil Environ 2012;58:141-7.

25. Cakmak I, Ozkan H, Braun HJ, et al. Zinc and iron concentrations in seeds of wild, primitive, and modern wheats. Food Nutr Bull 2000;21:401-3.

26. Peleg Z, Saranga Y, Yazici A, et al. Grain zinc, iron and protein concentrations and zinc-efficiency in wild emmer wheat under contrasting irrigation regimes. Plant Soil 2008;306:57-67.

27. Gao X, Mohr RM, McLaren DL, Grant CA. Grain cadmium and zinc concentrations in wheat as affected by genotypic variation and potassium chloride fertilization. Field Crops Res 2011;122:95-103.

28. Zhang Y, Song Q, Yan J, et al. Mineral element concentrations in grains of Chinese wheat cultivars. Euphytica 2010;174:303-13.

29. Fan MS, Zhao FJ, Fairweather-Tait SJ, et al. Evidence of decreasing mineral density in wheat grain over the last 160 years. J Trace Elem Med Bio 2008;22:315-24.

30. Rerkasem B, Jamjod S. Boron deficiency in wheat: a review. Field Crops Res 2004;89:173-86. 